\title{
Proliferative Myositis: A Rare Pseudosarcoma in Children
}

\section{Acharya AS, Kulkarni RV, Patrike SB and SG Nair}

Department of Pathology, M I M S R Medical College and Y C R Hospital, Latur, India

\begin{abstract}
Proliferative myositis is one of several benign, rapidly enlarging tumours of soft tissue that are often confused with sarcoma. We present an unusual case of proliferative myositis in a 7 year female involving right submandibular region. Proliferative myositis is a rare, inflammatory tumour that is often misdiagnosed as sarcoma. The clinical course of proliferative myositis is benign, and simple excision is curative.
\end{abstract}

Keywords: Child; Proliferative myositis; Pseudosarcoma

\section{Introduction}

Proliferative Myositis (PM), first described by Kern in 1960, is a rare pseudosarcomatous lesion with special predilection for trunk and upper extremities, though it rarely involves the head and neck region [1]. Majority of the patients are over the age of 45 years, but it may be seen in children also [2]. Its rapid growth and bizarre microscopic appearance often lead to misdiagnosis of soft tissue sarcoma [3]. Herein, we are reporting a similar interesting case of proliferative myositis in female child, diagnosed on histopathology.

\section{Case Report}

A 7 year old female child was admitted in YCR hospital, Latur with complaint of painless swelling in right submandibular region, since last 3 months. The patient had no history of trauma. On physical examination, immobile mass measuring $4 \times 4 \mathrm{~cm}$ was palpated in right submandibular region. The lump was not fixed to overlying skin and fixed to deeper tissue. It did not appear to be inflamed. Laboratory examination revealed leucocytosis with a White Blood Cell count of $13,200 / \mathrm{mm}^{3}$.

Ultasonographic findings showed a hypoechoic lesion involving the right mylohoid muscle without prominent vascularity, suggesting a soft tissue neoplasm. Considering the ultrasonographic findings, Fine needle aspiration cytology was planned and performed which was reported as inconclusive aspirate. However, in view of high clinical suspicion of soft tissue neoplasm, the lesion was widely excised and sent to histopathology department.

On gross examination, we received a nodular mass measuring $4 \times 3$ $\times 3 \mathrm{~cm}$. The cut surface was solid, grey white, soft to firm in consistency. No evidence of areas of haemorrhages and necrosis (Figure 1).

Microscopy revealed poorly circumscribed lesion showing cellular proliferation of fibroblasts surrounding the muscles and very large

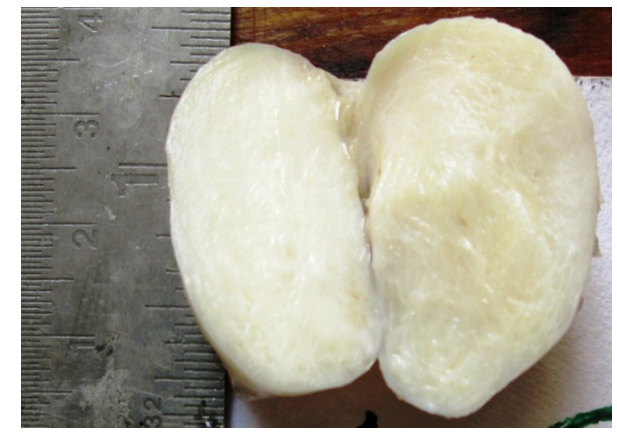

Figure 1: Gross photograph showing nodular grey white soft tissue mass. basophilic cells with vesicular nuclei and prominent nucleoli resembling ganglion cells. Few strips of muscle fibre noted at the periphery. There were no abnormal mitotic figures noted (Figures 2 and 3). Thus, the case was finally diagnosed as proliferative myositis on histopathology.

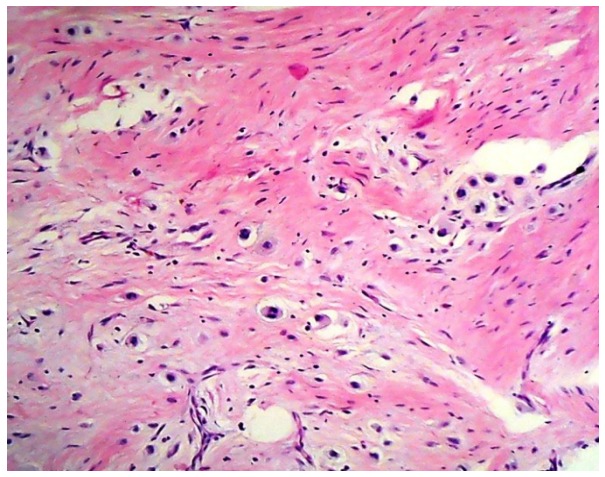

Figure 2: Microscopic appearance of proliferative myositis showing proliferating fibroblast with intermixed ganglion like cells (10X).

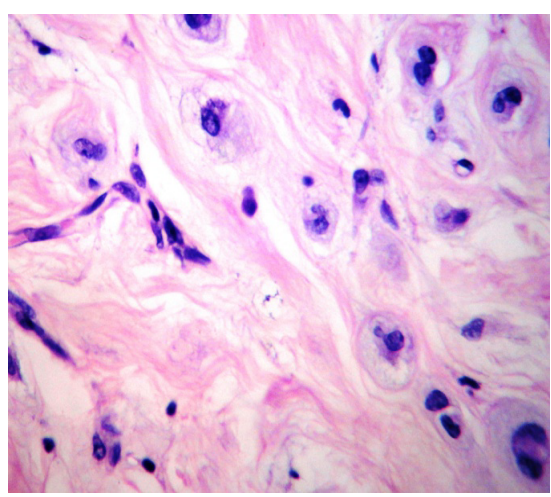

Figure 3: Figure showing ganglion like cells (40X).

*Corresponding author: Acharya AS, Department of Pathology, M.I.M.S.R medical college and Y.C.R Hospital Latur, India, Tel: 9404651225; Email: drabhijitacharya@gmail.com

Received December 10, 2014; Accepted January 24, 2015; Published January 26, 2015

Citation: Acharya AS, Kulkarni RV, Patrikeand SB, SG Nair (2015) Proliferative Myositis: A Rare Pseudosarcoma in Children. J Clin Case Rep 5: 487. doi:10.4172/2165-7920.1000487

Copyright: ( 2015 Acharya AS, et al. This is an open-access article distributed under the terms of the Creative Commons Attribution License, which permits unrestricted use, distribution, and reproduction in any medium, provided the original author and source are credited. 


\section{Discussion}

Proliferative myositis is rapidly growing benign soft tissue tumor often misdiagnosed as sarcoma [3]. It was first described by Kern in 1960 [1]. The lesion predominantly seen in trunk and upper extremities, though it rarely involves the head and neck muscles $[1,4]$. It is characterized as a firm, painless soft tissue mass. It measures $1-6 \mathrm{~cm}$ in diameter, rarely associated with tenderness or pain. It may double in size within a period of few days [5].

The symptoms of PM are nonspecific and the diagnosis always based on histological examination of tissue obtained by biopsy or excision of mass [5]. Adults are usually affected with a peak incidence between 40 and 70 years [3]. Reports of cases in children are extremely uncommon [6-8]. Most of the patient reports a rapidly enlarging soft tissue mass, usually affecting shoulder girdle and upper extremity [3]. Proliferative myositis may also rarely involve the soft tissue of head and neck [3,4]. In series of 33 cases reported by Enzinger and Dulcey, 18 involved shoulder and arm whereas only 4 cases arose from anterior chest wall [5].

Ultrasonography showed solid, ill-defined, soft tissue mass causing an expansion of right myelohoid muscle. Many cases of proliferative myositis shows a typical checkerboard, dry-cracked mud, or scaffolding like appearances, which is a valuable sonographic finding for an accurate diagnosis of proliferative myositis [6]. Proliferative myositis typically appears as pale gray or scar like induration of the involved skeletal muscle. Histologically, it shows proliferating connective tissue surrounding the viable muscle fibers and bizarre giant cells having close resemblance to ganglion cells or rhabdomyoblasts. The distinction between Proliferative Myositis and other pseudosarcomatous condition is extremely difficult.

The term pseudosarcoma includes three benign soft tissue tumors: nodular fascitis, Proliferative Myositis, and proliferative fascitis. Of the three, Proliferative Myositis is the least common, with fewer than 100 cases reported in the literature [3].The first three cases were presented in abstract form by Ackerman in 1958 [9]. The disease was subsequently named by Kern, who reported seven cases in 1960 [3]. Enzinger and Dulcey reported the largest series of 33 cases in 1967 [5]. Although PM is rare it is an important clinical entity because of confusion with highgrade sarcoma [3].

In childhood cases the important differatial diagnosis is rhabdomyosarcoma [10]. The history of rapidly enlarging mass of shorter duration and maximum size less than $3 \mathrm{~cm}$ favours reactive process than a sarcoma. Ganglion like cells of Proliferative Myositis lacking cross- strations show more cytoplasmic basophilia than rhabdomyoblast histologically too [10]. The immunohistochemical profile also shows negativity for desmin, myoglobin, and myogenin in the ganglion like cells [11]. The etiology of Proliferative Myositis is unknown. Approximately one third of patients will report a history of recent trauma to exact location of the lesion. Subclinical vascular injury may also be a precipitating event $[3,6]$. The prognosis of patient with Proliferative Myositis is excellent [1].
The current therapeutic approach involves understanding of selflimited nature of disease. Investigation includes fine needle aspiration cytology or incisional biopsy to exclude malignancy, and close follow up of the patient. However, complete excision of lesion may be necessary in cases with inconclusive biopsy findings. It is adequately treated by local excision.

\section{Conclusion}

Proliferative myositis, a pseudosarcomatous lesion of skeletal muscle, is quite rare in the pediatric population. While benign, it is not always recognized as such, and may be treated with an extensive resection. We highlight the importance of considering proliferative myositis in the differential diagnosis of a soft tissue mass, which ultimately might prevent an overly aggressive resection in a child.

\section{References}

1. Kern WH (1960) Proliferative myositis; a pseudosarcomatous reaction to injury: a report of seven cases. Arch Pathol 69: 209-216.

2. Meis JM, Enzinger FM (1992) Proliferative fasciitis and myositis of childhood Am J Surg Pathol 16: 364-372.

3. Kent MS, Flieder DB, Port JL, Altorki NK (2002) Proliferative myositis: a rare pseudosarcoma of the chest wall. Ann Thorac Surg 73: 1296-1298.

4. Dent CD, DeBoom GW, Hamlin ML (1994) Prolifrative myositis of head and neck. Report of a case and review of literature. Oral Surg Oral Med Oral Path 78: 354 .

5. Enzinger FM, Dulcey F (1967) Proliferative myositis. Report of thirty three cases. Cancer 20: 2213.

6. Mulier S, Stas M, Delabie J, Lateur L, Gysen M (1999) Proliferative myositis in a child. Skeletal Radiol 28: 703-709.

7. Mulier S, Stas M, Delabie J, Lateur L, Gysen M (1995) Polifrative myositis in child. A case report. J Bone Joint Surgery (Am) 77:132.

8. Pollock L, Fullilove S, Shaw D (1995) Proliferative myositis in child. A case report. J Bone Joint Surg (Am) 77:132.

9. Ackerman LV (1958) Extra osseous localized non-neoplastic bone and cartilage formation so-called myositis ossificance): clinical and pathological confusion with malignant neoplasm. J Bone Joint Surg (Am) 40-A: 279.

10. Enzinger and Weiss's (2013) Soft Tissue Tumors. (6thedn.) Mosby Elsevier.

11. Brooks JS (1981) Immunohistochemistry of proliferative myositis. Arch Pathol Lab Med 105: 682. 